\title{
児童の関係性攻撃における自己評定と 仲間評定の比較
}

\section{勝間理沙 ${ }^{1}$ 兵庫教育大学 山崎勝之 鳴門教育大学}

\section{A comparison of self- and peer-reports of relational aggression in elementary school children}

Lisa Katsuma (Hyogo University of Teacher Education)

and Katsuyuki Yamasaki (Naruto University of Education)

\begin{abstract}
A number of different methods for assessing relational aggression have been utilized in previous research. It has been suggested that scores on self-report measures of relational aggression especially in children and adolescents are not associated with scores on other types of measures, suggesting that peer-report measures are more accurate. Nevertheless, few prior studies have directly compared self-and peer-reports. The purpose of the current study was to investigate which type of report is superior. We first developed a new questionnaire to measure relational aggression by self and peers. Elementary school children (grades fourth to sixth; $n=243$ ) completed this questionnaire. In addition, their teachers nominated high and low relational-aggressive children in their classes. The two reports were different in terms of correlational analyses, but were almost the same with regards to grouprelated analyses using analyses of variance (ANOVAs). Moreover, girls' peer-reports were more similar to the teacher nominations than they were to their self-reports, and boys also showed a similar trend. We discuss how selfand peer-reports should be used in future studies.
\end{abstract}

Key words: relational aggression, self-reports, peer-reports.

The Japanese Journal of Psychology

2008, Vol. 79, No. 3, pp. 263-268

これまで攻撃性として研究されてきたものの多く は，身体的攻撃や言語的攻撃であり，それらは非行や 犯罪行為などの外在的な問題を引き起こすリスク要因 となりやすいことが明らかにされてきた（Khatri， Kupersmidt, \& Patterson, 2000)。しかし近年，それとは 異なるタイプの攻撃性として, 関係性攻撃（relational aggression）に着目した研究が行われるようになって きた。関係性攻撃とは，自分の目的を達成するため に, 他者の人間関係や集団に扮ける受容感情にダメー ジを与えることで危害を加える行動と定義されている (Crick, 1996; Crick \& Grotpeter, 1995)。自分の思い通り にするため，または誰かを罰するために，他者を完全 に無視したり，報復として社会的に疎外したり，自分 の要求に従わないと友だち関係を止めると脅したりす る行為を指す (Crick, Werner, Casas, O’Brien, Nelson,

Correspondence concerning this article should be sent to: Lisa Katsuma, Developmental Health Psychology (Yamasaki) Laboratory, Department of Human Development, Naruto University of Education, Takashima, Naruto 772-8502, Japan(e-mail: e0620101@naruto-u.ac. jp)

本研究の実施にあたり, 多くの小学校の先生方, 児童の皆さ んにご協力頂きました。厚く御礼申し上げます。
Grotpeter, \& Markon, 1999)。

関係性攻撃には，間接的攻撃（indirect aggression） や社会的攻撃（social aggression）という類似した概念 がある。間接的攻撃は“加害者の意図が分からないよ うな方法を用いる (Lagerspetz, Björkqvist, \& Peltonen, 1988)”といった攻撃性の“間接的”な性質に焦点を 当てている。また一方で社会的攻撃は, より包括的に 直接的または間接的によらず，他者に対して“社会 的”にダメージを与えるものと定義されている (Galen \& Underwood, 1997)。このように, それぞれの 概念が定義している特徴の強調点に違いはあるが, “他者を社会的に排除するまたは操作する”という点 では共通していると Archer \& Coyne（2005）は述べて いる。本稿では, 本邦でも盛んに研究され（坂井・山 崎, 2003，2004a), 質問紙としても標準化されている 尺度が存在する (坂井・山崎, 2004b), 関係性攻撃の 研究を中心にするが, 他の二つ概念の研究結果も随所 で参照する。

関係性攻撃を語る上で, 論議される問題の一つとし て，関係性攻撃の個人的で，相対的に隠れた（covert） 性質のために，その測定が容易ではないことが指摘さ 
れている (Archer \& Coyne, 2005; Crick et al., 1999)。ま ず観察法については，質問紙などの調査法の実施が難 しい就学前児から児童期前期などで行われることが多 い（Feshbach, 1969)。しかし，観察法においては，観 察者が観察する仲間集団（関係）について前もって知 識がなければ，例えば，無視するという関係性攻撃の 行為が 2 人の子どもの間に観察されたとしても，2 人 の子どもの間に関係性がないから無視しているように 見えるのか，無視しているから関係性がないのかとい った判断が歪む可能性が懸念されている (Crick et al., 1999)。

児童期以降に抢いては，たいてい質問紙調查が行わ れているが，それらの調査は，評定者の違いにより， 仲間，教師あるいは親による評定である他者評定およ び自己評定に分けられる。一般的な質問紙調査では, 攻撃性のような社会的に望ましくない特徵について は，自己評定よりも他者による評定の方が精度が高く なることが知られている。関係性攻撃研究において も，自他両方の評定で測定されているが，他者評定で は，仲間評定と教師（親）評定間では高い相関を示す が，特に児童期や青年期に扮いては，自己評定はその 他の評定方法とは必ずしも関連を示さないことが指摘 されている (Crick et al., 1999)。また，児童期では， 1 日の多くの時間を一緒に過ごす仲間は，もっとも重要 な存在であり，友だちがいることや仲間に受け入れら れることが，子どもたちにとって極めて大切なことと なる (Parker \& Gottman, 1989)。つまり児童期では, 仲間はもっとも重要な存在であり, 測定対象の児童 を，教師や親よりも，ひいては児童自身よりも正確に 知る存在である可能性は高い。このようなことも併 せ, Archer \& Coyne (2005) は，児童期における関係 性攻撃の測定は，仲間による評定がもっともふさわし いであろうと結論づけている。しかし一方で，仲間評 定法の実施については, 特に学校現場などにおいて は，否定的な表現を伴う攻撃性を仲間評定として級友 に評価させるという教育，倫理上の問題が伴うことも 事実である。このような現状に対して, Crick et al. （1999）は，他者評定を得ることが困難な状況下では， 今後の研究において, 関係性攻撃の自己評定の有用性 を調べていくことが重要であると述べている。

しかし現時点では, 実際に関係性攻撃に抒ける自己 評定と他者評定を比較した研究はほとんどない。間接 的攻撃の研究では, 副次的ではあるが, Lagerspetz et al.（1988）が，間接的攻撃と直接的攻撃を対比した研 究において，それぞれの攻撃性に自己評定と仲間評定 を用い, 間接的攻撃の自己評定と仲間評定間に, $r=$ .23-.24 という，有意ではあるが，それほど高くない 相関を提示している。この結果から関係性攻撃につい ても, 自己評定と他者評定では, 両者はほとんど関連 しないことが類推される。自己評定と他者評定からの
関係性攻撃が関連していないとするならば，どちらか がより正確に関係性攻撃を捉えていると言えるのだろ うか。あるいは，それぞれが正確に関係性攻撃を捉え てはいるが，異なった側面を捉えているのだろうか。 その点に言及した研究は，間接的攻撃や社会的攻撃と いった類似する概念における研究を併せても皆無であ ろう。

そこで, 学校場面では比較的実施が容易である自己 評定での測定の可能性を探るためにも, 実際に児童期 の自己評定と他者評定, 特に仲間からの評定を対比 し，それらの性質を明らかにする。さらに自己と仲間 のどちらからの評定がより関係性攻撃を捉えることが できるかを判断するために, 教師評定（ノミネート法 による）を基準として検証することを本研究の目的と した。

\section{方 法}

\section{調査協力者}

和歌山県の公立小学校 3 校に在籍する小学校 4-6 年生 248 名（男子 124 名, 女子 124 名）およびその担 任 11 名を対象として調査を行った。そのうち, 小学 生については, 自己評定ならびに仲間評定に欠損值が あった 5 名を, また担任では, 回答を得られなかった 1名を分析から除外した。その結果, 最終分析対象者 は, 小学生では計 243 名（男子 122 名, 女子 121 名) であり, 各学年の内訳が, 4 年生 128 名（男子 64 名, 女子 64 名), 5 年生 55 名 (男子 28 名, 女子 27 名), 6 年生 60 名（男子 30 名, 女子 30 名）となり, 担任 は計 10 名（男性 7 名, 女性 3 名）となった。

\section{調査材料および調査手続き}

自己評定と仲間評定によって関係性攻撃を測定する 質問紙を, 本研究のために新たに開発し使用した。質 問紙の開発は, 次の手順で行われた。まず, Archer \& Coyne（2005）のレビュー論文をもとに，これまで児 童期を対象として用いられた関係性攻撃，間接的攻撃 ならびに社会的攻撃を測定する質問紙 (Crick, 1996; Galen \& Underwood, 1997; Lagerspetz et al., 1988; 坂井 • 山崎，2004b）の中で, 内容が共通していると思われ る項目を四つ選出した。さらに, 教育, 倫理面を考慮 して, すべての項目を, 本来の内容とは反対の意味に なるように説明する文とした(“ある子がみんなから きらわれるようなうわさ話を広めることはしない”, “言うことを聞いてくれない人の悪口を, 友だちとい つしょになって言わない”, “遊ぶときや班を作ると き，気に入らない友だちでも仲間に入れる”，“あの子 とは，いっしょに遊ばないで，とだれかにたのんだり しない”)。また併せて, 肯定的な雾囲気の項目を, 分 析には含めない無関項目として, 一つ挿入した(“学 
Table 1

教師ノミネート高群, 低群における関係性攻撃の自己評定および仲間評定の平均得点(標準偏差)

\begin{tabular}{|c|c|c|c|c|c|c|c|c|}
\hline & \multicolumn{4}{|c|}{ 高群 } & \multicolumn{4}{|c|}{ 低群 } \\
\hline & 男子 & $n$ & 女子 & $n$ & 男子 & $n$ & 女子 & $n$ \\
\hline 自己評定 & $4.78(3.21)$ & 18 & $4.41(3.52)$ & 17 & $2.68(3.40)$ & 19 & $2.44(2.28)$ & 18 \\
\hline 他者評定 & $4.54(1.91)$ & 18 & $4.16(1.83)$ & 17 & $2.85(2.58)$ & 19 & $2.34(1.74)$ & 18 \\
\hline
\end{tabular}

校で楽しそうである”)。児童一人一人に対して，クラ スの同性の子全員の出席番号（本人も含む）が記され た名簿を用意し, それを見ながら, 先の五つの項目に 対して，それぞれの子や本人にどれくらいあてはまる かを 0-4の 5 段階で評定してもらった。選択肢につ いては, さらなる教育, 倫理的配慮から, “ぜんぜん あてはまらない”という言葉は選択肢として記載せ ず, 出席番号の隣に, 左端を 0 として 4 までの数字を 並べ, 右端の 4 の数字の上に“とてもよくあてはまる (4 点)”という言葉だけを記載した。

また担任に対しては，担任クラスの児童について， ノミネート用紙を使用した。この教師ノミネートは, 今回の関係性攻撃質問紙開発に際しての妥当性の基準 として用いるとともに，自己評定と仲間評定の精度の 基準として用いることとした。ノミネート用紙には, 関係性攻撃として“自分の気に入っている人だけを相 手にし，それが高じてだれかを孤立させようとしてし まう面がある”という説明文が記されており，この文 に表された内容について，そのような特徴が強い児童 と弱い児童を 2 人ずつ男女別に挙げてもらった（坂 井・山崎, 2004b)。

調査は2006 年 7 月にクラス単位で行われた。調査 に際して, 実施校の校長およびクラスの担任から許可 を得た。さらに，本調査が成績とは関係ないこととプ ライバシーは厳守される旨を記載した実施要項と, 関 係性攻撃質問紙を用意した。さらに，担任には，クラ スの同性の子全員の出席番号（本人も含む）が記され た名簿を用意してもらった。実施についてはそれぞれ の学級担任に依頼した。実施要項, 関係性攻撃質問紙 および出席名簿を児童に配布し, 実施要項を読み上げ た後，回答を始めることと，名簿を確認しながら回答 することを指示してもらった。質問紙は無記名であっ たが, データ識別のために出席番号だけを必ず記載し てもらった。すべての質問項目への回答には約 15 分 を要した。

\section{得点化}

まず，すべての質問項目が逆転項目であるため，点 数が高いほど, 関係性攻撃傾向が高くなるように変換 した。そして, 自分 (の出席番号) に対する評定を自 己評定とし（Lagerspetz et al., 1988），関係性攻撃に関 する 4 項目の合計得点を自己評定による関係性攻撃得
点とした。また，仲間評定については，各項目につい て, クラスメイト (同性) からの評定の平均得点を算 出し, 先の 4 項目の合計得点を仲間評定による関係性 攻撃得点とした。

\section{結 果}

\section{関係性攻撃質問紙の信頼性および妥当性の検討}

第 1 に, 本研究に際して作成した関係性攻撃質問紙 の信頼性と妥当性の確認を以下の手順で行った。

信頼性の検討については, クロンバックの $\alpha$ 係数 を算出した結果, 自己評定では $\alpha=.79$ (男子.74, 女 子.83), 仲間評定では $\alpha=.89$ (男子.86, 女子.92) と なり, 内的整合性が確認された。

さらに教師ノミネートによる妥当性の検討を行っ た。それぞれのクラスの担任教師が, ノミネート用紙 に示された関係性攻撃の特徵について, この特徴が強 いとノミネートした児童 (関係性攻撃・高群), 弱い とノミネートした児童（同・低群）の自己評定と仲間 評定別の平均得点と標準偏差を Table 1 に示した。そ れらをもとに，2要因（性×教師ノミネートによる関 係性攻撃高低群）の分散分析を行った。その結果, 自 己評定, 仲間評定いずれにおいても, その特徴が強い 子どもとしてノミネートされた児童の平均得点は, 特 徵が弱い子どもとしてノミネートされた児童の平均得 点より有意に高かった（自己評定: $F(1,68)=7.52$, $p<.01$, 他者評定 : $F(1,68)=13.12, p<.01)$ 。なお, 性の主効果 (自己評定 : $F(1,68)=.17, p>.05$, 他者 評定 : $F(1,68)=.84, p>.05)$ と交互作用（自己評 定 : $F(1,68)=.01, p>.05$, 他者評定 : $F(1,68)=.02$, $p>.05)$ はいずれも有意ではなかった。

以上の結果より, 本研究で用いられた関係性攻撃質 問紙は, 自己評定, 仲間評定についても十分な信頼性 と妥当性を有していることが示された。

\section{自己評定と仲間評定の性質の比較}

相関係数による検討 次に, 関係性攻撃質問紙の自 己評定と仲間評定とを比較検討するために，まずはじ めに, 自己評定と仲間評定による関係性攻撃得点間の 相関係数を算出した。Table 2 は, それを男女および 学年別にまとめたものである。その結果, 4 年生の男 子において, 自己評定と仲間評定による関係性攻撃得 
Table 2

自己評定と仲間評定による関係性攻撃得点間の相関係数

\begin{tabular}{llrrr}
\hline & 4 年生 & 5年生 & \multicolumn{1}{c}{ 6年生 } & \multicolumn{1}{c}{ 全体 } \\
\hline 男子 & $.45^{* *}$ & .04 & -.12 & $.25^{* *}$ \\
女子 & .06 & .29 & .06 & $.31^{* *}$ \\
全体 & $.23^{* *}$ & .17 & -.01 & $.28^{* *}$ \\
\hline${ }^{* *} p<.01$ & & &
\end{tabular}

Table 3

自己評定における関係性攻撃の平均值 (標準偏差)

\begin{tabular}{lccccrr}
\hline & 男子 & $n$ & 女子 & $n$ & 全体 & $n$ \\
\hline 4年生 & $2.94(2.67)$ & 64 & $2.95(3.28)$ & 64 & $2.95(2.98)$ & 128 \\
5年生 & $4.34(4.31)$ & 28 & $6.15(4.16)$ & 27 & $5.22(4.30)$ & 55 \\
6年生 & $3.20(3.45)$ & 30 & $2.63(2.71)$ & 30 & $2.92(3.09)$ & 60 \\
全体 & $3.32(3.32)$ & 122 & $3.59(3.62)$ & 121 & $3.45(3.47)$ & 243 \\
\hline
\end{tabular}

Table 4

仲間評定における関係性攻撃の平均値(標準偏差)

\begin{tabular}{lccccrr}
\hline & 男子 & $n$ & 女子 & $n$ & 全体 & $n$ \\
\hline 4年生 & $3.12(1.70)$ & 64 & $2.81(1.64)$ & 64 & $2.96(1.67)$ & 128 \\
5年生 & $5.10(1.99)$ & 28 & $5.34(1.93)$ & 27 & $5.22(1.97)$ & 55 \\
6年生 & $3.01(.83)$ & 30 & $2.87(1.47)$ & 30 & $2.94(1.19)$ & 60 \\
全体 & $3.54(1.81)$ & 122 & $3.39(1.96)$ & 121 & $3.46(1.89)$ & 243 \\
\hline
\end{tabular}

点間に, 中程度の有意な正の相関が認められた。しか し, 男子におけるその他の学年や女子のすべての学年 においては, 有意な相関は認められなかった。ただ し, 全体の結果として見ると, 男子および女子, そし てさらに, 4 年生において相関が有意となっていた。

学年および性差の検討 相関係数では, 自己評定と 仲間評定の直接的な関連性を検討した。そこで次に, 自己評定と仲間評定の，何らかの外的な基準，例えば 群差の捉え方について, さらに検討する必要があると 考えた。そこで, 本研究のデータから利用できる学年 差と性差という群差について, 自己評定と仲間評定に おける群差の捉え方の差異を検討することとした。そ のために Table 3, Table 4 に示した平均得点と標準 偏差をもとに，自己評定と仲間評定それぞれについて 2 要因 (学年 $\times$ 性) の分散分析を行った。

まず自己評定においては，学年の主効果が見られ $(F(2,237)=10.11, p<.01)$, その後の Scheffe 法を用 いた検定で，4，6年生よりも5 年生の方が有意に関 係性攻撃得点が高いという結果を示した。なお，性の 主効果および交互作用は有意ではなかった $(F(1$, $237)=.86, p>.05 ; F(2,237)=2.06, p>.05)$ 。また, 仲間評定においても，学年における主効果が見られた
$(F(2,237)=40.40, p<.01)$ 。その後の Scheffe 法によ る検定において，4，6年生よりも5 年生の方が仲間 から関係性攻撃が有意に高いと評定されていた。ま た，性の主効果および交互作用は有意ではなかった $(F(1,237)=.09, p>.05 ; F(2,237)=.55, p>.05) 。$

分散分析の結果からは, 関係性攻撃に対する自己評 定と仲間評定の学年および性差において同じ傾向が見 出された。

\section{教師ノミネートを基準とした自己評定と仲間評定の精 度の検討}

さらに, 自己評定と仲間評定のどちらがより関係性 攻撃を捉えることができるかを判断することとした。 そこで, 教師ノミネートを基準として, 関係性攻撃傾 向が高い（低い）とノミネートされた児童について， その仲間評定および自己評定の高さ（低さ）を比較 し, どちらがより教師の判断に近い評定となっている かを検討した。つまり, 教師ノミネートの結果との類 似性によって, 精度の高低を検討し, 類似しているほ ぞ精度が高いと推測した。

はじめに分析に際して, 自己評定得点と仲間評定得 点について, 各クラス男女ごとに得点が低い順に順位 
Table 5

自己評定および仲間評定関係性攻撃得点順位平均 (標準偏差) と評定差

\begin{tabular}{|c|c|c|c|c|c|c|c|c|c|c|}
\hline & \multicolumn{5}{|c|}{ 教師ノミネート高群 } & \multicolumn{5}{|c|}{ 教師ノミネート低群 } \\
\hline & 自己評定 & $n$ & 仲間評定 & $n$ & $Z$ & 自己評定 & $n$ & 仲間評定 & $n$ & $Z$ \\
\hline 男子 & $6.28(3.06)$ & 18 & $7.94(3.46)$ & 18 & $-1.77^{+}$ & $4.42(3.06)$ & 19 & $3.42(2.83)$ & 19 & -1.19 \\
\hline 女子 & $6.59(3.10)$ & 17 & $8.59(3.48)$ & 17 & $-2.14^{*}$ & $5.22(3.93)$ & 18 & $3.89(2.93)$ & 18 & -.91 \\
\hline
\end{tabular}

${ }^{*} p<.05, .05<{ }^{+} p<.10$

を付けた。そして，各クラスの担任教師が，関係性攻 撃を説明した文について，その傾向が高いまたは低い とノミネートした児童の自己評定得点と仲間評定得点 の順位だけを抽出した。そしてそれをもとに，教師ノ ミネート高群および低群における自己評定と仲間評定 関係性攻撃得点順位の差を検討するために Wilcoxon の符号付き順位検定を行った。その結果, 教師ノミネ 一ト高群の女子において, 仲間評定得点順位平均が自 己評定得点順位平均よりも有意に高くなり, 男子にお いては，有意傾向であったが，同様の結果が見られ た。なお, 教師ノミネート低群については, 男子にお いても, 女子においても, 自己評定と仲間評定による 有意な差異は見られなかった（Table 5)。

\section{考察}

以上の結果を受け，児童の関係性攻撃における自己 評定と仲間評定の性質が明らかにされた。

まず相関係数では, 全体の相関係数では, 男女に有 意な正の相関が認められた。しかし，学年，男女別に 見た場合, 4 年生の男子にのみ, 関係性攻撃に対する 自己評定と仲間評定に有意な正の相関が見られた。全 体の結果において, 4 年生の学年全体と女子全体に有 意な正相関が見られたのは，4年生男子の結果が影響 している可能性が高い。そのため, 相関係数の結果か らは，自己評定と仲間評定でも同様の関係性攻撃を測 定できるのは，4 年生男子においてのみであると考え られる。男女別で見た場合は，先に示した Lagerspetz et al. (1988) の結果とほぼ同じ值が得られており, こ の結果からも, 関係性攻撃における自己評定と仲間評 定はあまり関連していない結果となっている。しか し, 学年差と性差から関係性攻撃における自己評定と 他者評定の性質を見るために分散分析を行った結果,

自己評定と仲間評定両者とも学年においてのみ主効果 が見られ，その結果に同じ傾向が見られた。この結果 については, 本研究のサンプル数が比較的少ないた め, 今回の群差の分析結果をそのまま一般化すること ができない。しかし, 本研究での関係性攻撃の測定法 については, 自己評定においても, 仲間評定において も, 信頼性, 妥当性を確認しており, ぞちらの評定に おいても標準的に関係性攻撃を捉えていることにな る。それでは, 相関係数では 4 年生男子以外では, 評
定間の類似性が見られなかった一方で，分散分析の結 果では, 評定間の傾向は同じであったというこれらの 結果はいかなることか。考えられることとしては, 群 差のように (中央値で) 大まかに分けた集団間では, 自己評定と仲間評定における反応傾向は類似するが, 相関係数等の分析で両者の関連を集団内の個々人の自 己評定と仲間評定の反応について見た場合，自己によ る評定と仲間による評定は一致していない可能性が高 いということである。つまり, 自己評定と仲間評定で は関係性攻撃の異なる側面を表している可能性があ る。仲間はどのような意困で行われた関係性攻撃かを 正確に判断することはできず, 主として, 外に現れた 行動から関係性攻撃を捉えている。一方, 自己評定で は自分がその行動を行う意図の観点から関係性攻撃を 捉えることが多いことが推測される。そのようなズレ が, 評定の不一致を生じさせている可能性が高い。こ のような可能性があるならば, 関係性攻撃は, “意図 的に”行われる攻撃である (Crick \& Grotpeter, 1995) ため, 自己評定の方がより関係性攻撃の本来の姿を捉 えられることも考えられる。

そこでさらに本研究では, どちらがより関係性攻撃 を捉えているのかを判断するために, 教師ノミネート を基準として検討した。その結果からは，教師に関係 性攻撃が高いとノミネートされた女子では, それぞれ の評定ごとに低い順に並べたとき，仲間評定が自己評 定よりも有意に高い順位となっており, 男子では有意 に高い順位となっている傾向があり, 評定差が確認さ れた。よって, 教師を基準としたとき, より関係性攻 撃が高い児童に関しては, 仲間評定の方がより関係性 攻撃を捉えられると判断できる。しかし, 今回は対象 となる児童を知る者としてデータの採取が比較的容易 である教師を基準としたが，教師が担任児童の実態を 正確に把握していない可能性は否定できない。また, 教師ノミネート低群に関しては, 有意な差が見られな かったことからも, どちらが関係性攻撃を測定するの にふさわしいかということまでは結論づけることはで きない。精度については, 例えば, 長期的に観察を行 い, そこから得られたデー夕を基準に, 自己評定と仲 間評定では，どちらが一致しているかを検討するとい う方法が考えられる。今後, ぞちらの評定がより関係 性攻撃にふさわしいかという精度に関しては，このよ 
うなさらに厳密な基準を用いて検討していくことが必 要であろう。

関係性攻撃が，応用的な場面で問題となるのは，い じめとの関わりである。現在, いじめは学校現場でも 重要な問題となっており, 関係性攻撃的ないじめは深 刻な被害をもたらしていくことが予測される。関係性 攻撃に対処する方略を模索していく上でも，その測定 法の問題は重要となってくるだろう。本研究に拀ける 関係性攻撃の自己評定と仲間評定の比較では，それぞ れの評定が示している意味合いに違いがある可能性を 示唆することはできたが，その上で，ぞちらが有効で あるかという精度までを明らかにすることはできなか った。ただし，これまで述べられてきた児童期の関係 性攻撃に打ける仲間評定の優位性は, 今回のデー夕か らは得られず，自己評定と仲間評定には，決定的な優 劣が認められなかったことも事実である。むしろ，自 己評定における可能性を示唆したと言えるだろう。こ のような結果は, 抢そらく関係性攻撃研究の中では初 めての知見であり, 今後研究を重ねていくことの重要 性を提示した。ただし，そのような知見が重ねられる までは，実施が可能である限り，Xie, Cairns, \& Cairns (2005) が述べているように, 単一の測定による制限 を補うために，子どもの関係性攻撃の評定は，多面的 なアプローチから評定されることが望ましいだろう。

\section{引用文献}

Archer, J., \& Coyne, S. M. (2005). An integrated review of indirect, relational, and social aggression. Personality and Social Psychology Review, 9, 212-230.

Crick, N. R. (1996). The role of overt aggression, relational aggression, and prosocial behavior in the prediction of children's future social adjustment. Child Development, 67, 2317-2327.

Crick, N. R., \& Grotpeter, J. K. (1995). Relational aggression, gender, and social-psychological adjustment. Child Development, 66, 710-722.

Crick, N. R., Werner, N. E., Casas, J. F., O’Brien, K. M., Nelson, D. A., Grotpeter, J. K., \& Markon, K. (1999). Childhood aggression and gender : A new look at an old problem. Nebraska Symposium on Motivation, 45, 75-141.

Feshbach，N. D. (1969). Sex differences in children's modes of aggressive responses toward outsiders.
Merrill-Palmer Quarterly, 15, 249-258.

Galen, B. R., \& Underwood, M. K. (1997) . A developmental investigation of social aggression among children. Developmental Psychology, 33, 589-600.

Khatri, P., Kupersmidt, J. B., \& Patterson, C. (2000). Aggression and peer victimization as predictors of selfreported behavioral and emotional adjustment. Aggressive Behavior, 26, 345-358.

Lagerspetz, K. M., Björkqvist, K., \& Peltonen, T. (1988). Is indirect aggression typical of females? Gender differences in aggressiveness in 11-to 12-year-old children. Aggressive Behavior, 14, 403-414.

Parker, J. G., \& Gottman, J. M. (1989). Social and emotional development in a relational context: Friendship interaction from early childhood to adolescence. In T. J. Berndt \& G. W. Ladd (Eds.), Peer relationships in child development. New York: Wiley. pp. 95-131.

坂井明子・山崎勝之 (2003). 小学生における 3 夕イ プの攻撃性が抑うつと学校生活享受感情に及ぼす 影響 学校保健研究, 45, 65-75.

(Sakai, A., \& Yamasaki, K. (2003). The effects of three types of aggressiveness on depression and enjoyment of school life in elementary school children. Japanese Journal of School Health, 45, 65-75.)

坂井明子・山崎勝之 (2004a). 小学生における 3 夕イ プの攻撃性が攻撃反応の評価抒よび結果予期に及 ぼす影響 教育心理学研究， 52， 298-309.

(Sakai, A., \& Yamasaki, K. (2004a). Children's evaluations and outcome expectations for aggressive responses and types of aggressiveness. Japanese Journal of Educational Psychology, 52, 298-309.)

坂井明子 - 山崎勝之 (2004b). 小学生用 P-R 攻撃性質 問紙の作成と信頼性, 妥当性の検討 心理学研 究, 75, 254-261.

(Sakai, A., \& Yamasaki, K. (2004b). Development of the proactive and reactive aggression questionnaire for elementary school children. Japanese Journal of Psychology, 75, 254-261.)

Xie, H., Cairns, B. D., \& Cairns, R. B. (2005). The development of aggressive behaviors among girls: Measurement issues, social functions, and differential trajectories. In D. J. Pepler, K. C. Madsen, C. Webstre \& K. S. Levene (Eds.), The development and treatment of girlhood aggression. Mahwah, $\mathrm{NJ}$ : Lawrence Erlbaum Associates. pp. 105-136.

-2007. 2.2 受稿, 2008.1.12 受理— 